\title{
NK cell upraise in the dark world of cancer stem cells
}

\author{
Alireza Shokouhifar ${ }^{1,2,3}$, Javad Firouzi ${ }^{3,4}$, Masoumeh Nouri ${ }^{5}$, Gholamreza Anani Sarab ${ }^{2^{*}}$ and \\ Marzieh Ebrahimi ${ }^{3,6^{*}}$ (])
}

\begin{abstract}
One of the obstacles in treating different cancers, especially solid tumors, is cancer stem cells (CSCs) with their ability in resistance to chemo/radio therapy. The efforts for finding advanced treatments to overcome these cells have led to the emergence of advanced immune cell-based therapy (AICBT). Today, NK cells have become the center of attention since they have been proved to show an appropriate cytotoxicity against different cancer types as well as the capability of detecting and killing CSCs. Attempts for reaching an off-the-shelf source of NK cells have been made and resulted in the emergence of chimeric antigen receptor natural killer cells (CAR-NK cells). The CAR technology has then been used for generating more cytotoxic and efficient NK cells, which has increased the hope for cancer treatment. Since utilizing this advanced technology to target CSCs have been published in few studies, the present study has focused on discussing the characteristics of CSCs, which are detected and targeted by NK cells, the advantages and restrictions of using CAR-NK cells in CSCs treatment and the probable challenges in this process.
\end{abstract}

Keywords: NK cell, CSC, Immune cell-based therapy, CAR

\section{Dormant stem cells hidden inside tumors}

Cancer is one of the major mortality causes worldwide, accounting for about $20 \%$ of deaths in the developed countries annually [1]. Today, according to numerous clinical and preclinical studies, there are several available diagnostic and therapeutic methods that play crucial roles in the therapeutic and preventive processes [2]. Common therapies including surgery, radiotherapy, and chemotherapy have low degrees of efficacy in the treatment and also relief from recurrence [3]. One of the main reasons for cancer progression, metastasis and its treatment failure is tumor cells heterogeneity and the dormant cells with special ability of tumor development. These

\footnotetext{
*Correspondence: ghansa@yahoo.com; m.ebrahimi@royan-rc.ac.ir

${ }^{2}$ Cellular \& Molecular Research Center, Birjand University of Medical

Sciences, Birjand, Iran

${ }^{3}$ Department of Stem Cells and Developmental Biology, Cell Science Research Center, Royan Institute for Stem Cell Biology and Technology, ACECR, 16635-148 Tehran, Iran

Full list of author information is available at the end of the article
}

dormant cells, called cancer stem cells (CSCs), [4] are characterized by self-renewal, proliferation, differentiation into multiple cell types and drug resistance potential and are considered as the sparks of primary tumor cells [5]. Based on the evaluation of stemness characteristics and specific surface markers, CSCs can be distinguished from among the other tumor cells by identification methods listed in Table 1. Single-cell sequencing is one of the powerful tools for identifying CSCs from among other cells. Single-cell sequencing including single-cell transcriptome, epigenome, and genome sequencing technologies is used for characterizing the omic-scale features of heterogeneous cell populations such as stem cells. Many studies have demonstrated that hematopoietic stem cells, pre-leukemic stem cells and leukemic stem cells can be distinguished through combining single-cell transcriptomics such as transcriptome and genome (G\&T-seq), transcriptome and DNA methylome (scM\&T-seq), or genome, DNA methylome and transcriptome (scTrioseq) $[6,7]$.

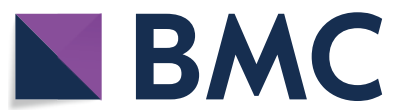

(c) The Author(s) 2021. Open Access This article is licensed under a Creative Commons Attribution 4.0 International License, which permits use, sharing, adaptation, distribution and reproduction in any medium or format, as long as you give appropriate credit to the original author(s) and the source, provide a link to the Creative Commons licence, and indicate if changes were made. The images or other third party material in this article are included in the article's Creative Commons licence, unless indicated otherwise in a credit line to the material. If material is not included in the article's Creative Commons licence and your intended use is not permitted by statutory regulation or exceeds the permitted use, you will need to obtain permission directly from the copyright holder. To view a copy of this licence, visit http://creativecommons.org/licenses/by/4.0/. The Creative Commons Public Domain Dedication waiver (http://creativeco mmons.org/publicdomain/zero/1.0/) applies to the data made available in this article, unless otherwise stated in a credit line to the data. 
Table 1 Characterization of cancer stem cells

\begin{tabular}{|c|c|c|c|}
\hline & Method & & Procedure \\
\hline \multirow{3}{*}{$\begin{array}{l}\text { Isolation and } \\
\text { identification } \\
\text { of CSCs }\end{array}$} & Side population detection & & Sorting based on Hoechst dye efflux \\
\hline & Cell surface markers detection & & Sorting based on cell surface marker expression \\
\hline & Culture of non-adherent & & Sphere culture \\
\hline \multirow{4}{*}{$\begin{array}{l}\text { Properties } \\
\text { and charac- } \\
\text { terization of } \\
\text { CSCs }\end{array}$} & Tumorgenicity assay & & $\begin{array}{l}\text { Implantation of a single CSC for generating the entire tumor } \\
\text { in a mouse model }\end{array}$ \\
\hline & Self-renewal & Serial transplantation (single cell) & $\begin{array}{l}\text { The low numbers of CSCs isolated from any generation of } \\
\text { tumor should be able to give rise to a subsequent tumor } \\
\text { in vivo }\end{array}$ \\
\hline & & In vitro renewal & $\begin{array}{l}\text { Measuring the ability to form colonies through multiple } \\
\text { generations in vitro }\end{array}$ \\
\hline & Establishment of tumor heterogeneity & & $\begin{array}{l}\text { Determination of CSC-derived tumor heterogeneity by flow- } \\
\text { cytometry (surface markers) or immunohistochemistry }\end{array}$ \\
\hline
\end{tabular}

The surface markers used based on tumor differentiation to identify CSCs are depicted in Table 2

As mentioned, cancer stem cells (CSCs) induce metastasis and therapy resistance $[5,8,9]$. The functional or molecular properties relevant to CSC populations such as deregulation of pathways involved in differentiation, self-renewal, apoptosis and survival, increased expression of ATP binding cassette (ABC)-related transporters to efflux toxic compounds, adaptation to hypoxia, increased DNA damage response and reactive oxygen species (ROS) scavenging, altered metabolism, evasion of immunosurveillance and anchorage-independent survival and quiescence can mediate the acquired resistance $[3,8,9]$. The tumor microenvironment (TME), including cancer-associated fibroblasts (CAF) and extracellular matrix (ECM), play a key role in drug resistance $[4,10]$. CSCs can be distinguished from the tumor-differentiated cells by evaluating the expression profiles of the surface markers classified in Table 2 based on tumor type. A number of CSCs targeted therapies which are proved to have the capability of preventing relapse have been depicted in Fig. 1.

Today, new therapies to overcome CSC resistance including epigenetic therapies, drugs targeting angiogenesis, immune cell-based therapies such as T, NK, and dendritic cells are rapidly developing, among which NK cells are of great interest because of their ability to identify and destroy cancer stem cells.

Table 2 The common surface markers on Different CSCs

\begin{tabular}{|c|c|c|}
\hline Malignancy & Surface marker & References \\
\hline Brain & $\mathrm{CD} 15+, \mathrm{CD}^{+} 0^{+}, \mathrm{CD}_{133^{+}}, \mathrm{ABCG}^{+}, \mathrm{CD}_{99}{ }^{+}, \mathrm{CXCR}^{+}, \mathrm{CD} 114^{+}$ & {$[22,29,30]$} \\
\hline Breast & 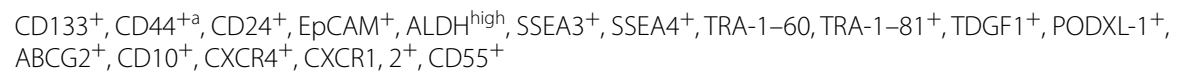 & {$[31-34]$} \\
\hline Colon & 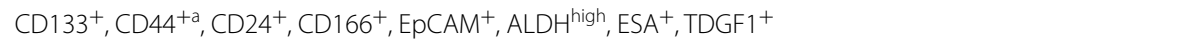 & {$[28,35,36]$} \\
\hline Endometr & $\mathrm{CD}_{4} 4^{+\mathrm{a}}, \mathrm{EpCAM}^{+}, \mathrm{CD}_{133^{+}}, \mathrm{ALDH}^{\text {high }}$ & {$[37,38]$} \\
\hline Gastric & $\mathrm{CD}_{133^{+}}, \mathrm{CD}_{4} 4^{+\mathrm{a}}, \mathrm{CD}_{2} 4^{+}, \mathrm{CD}_{4} 4^{+}, \mathrm{ALDH}^{\text {high }}, \mathrm{EpCAM}^{+}$ & {$[39,40]$} \\
\hline Hematological & $\mathrm{CD}_{19}{ }^{+}, \mathrm{CD}_{2} 6^{+}, \mathrm{CD}_{3} 4^{+}, \mathrm{CD}_{3} 8^{-}, \mathrm{CD}_{2} 23^{+\mathrm{a}}, \mathrm{PODXL}_{-1}^{+}, \mathrm{TIM}^{-} 3^{+}, \mathrm{CD} 6^{+}$ & {$[4,41-43]$} \\
\hline Head and Neck & $\mathrm{CD} 271^{+}, \mathrm{SSEA}-1^{+}, \mathrm{CD} 44^{+\mathrm{a}}, \mathrm{CD} 133^{+}, \mathrm{CD} 10+$ & {$[44,45]$} \\
\hline Liver & $\mathrm{CD}_{133^{+}}, \mathrm{CD}_{4} 4^{+\mathrm{a}}, \mathrm{CD}_{49 f^{+}}, \mathrm{CD} 0^{+}, \mathrm{ALDH}^{\text {high }}, \mathrm{ABCG}^{+}, \mathrm{CD}_{2} 4^{+}, \mathrm{ESA}^{+}, \mathrm{EpCAM}^{+}, \mathrm{CD} 3^{+}$ & [46-48] \\
\hline Lung & $\mathrm{CD}_{133^{+}}, \mathrm{CD}_{4}{ }^{+a}, \mathrm{ALDH}^{\text {high }}, \mathrm{ABCG}^{+}, \mathrm{CD} 7^{+}, \mathrm{CD} 0^{+}, \mathrm{SSEA} 1^{+}, \mathrm{TDGF}^{+},{\mathrm{PODXL}-1^{+}}^{+}, \mathrm{Notch}^{+}, \mathrm{CD} 6^{+}$ & [49-51] \\
\hline Melanoma & $\mathrm{ABCB}^{+}, \mathrm{CD}^{2} 0^{+}, \mathrm{CD} 271+$ & [52-54] \\
\hline Pancreas & $\mathrm{CD}_{133^{+}}, \mathrm{CD}_{4} 4^{+\mathrm{a}}, \mathrm{CD}_{2} 4^{+}, \mathrm{ALDH}^{\text {high }}, \mathrm{ABCG}^{+}, \mathrm{EpCAM}^{+}, \mathrm{ESA}^{+}, \mathrm{PODXL}^{-}{ }^{+}, \mathrm{Notch}^{+}, \mathrm{CXCR}^{+}, \mathrm{CXCR}, 2^{+}$ & [55-57] \\
\hline Prostate & $\mathrm{CD}_{133^{+}}, \mathrm{CD}_{4} 4^{+\mathrm{a}}, \mathrm{a}_{2} \mathrm{~B}^{+}, \mathrm{ALDH}^{\text {high }}, \mathrm{ABCG}^{+}, \mathrm{TRA}^{-1}-60^{+}$ & [58-60] \\
\hline Testis & SSEA3 $^{+}$, SSEA $^{+}{ }^{+}$, TRA $-1-60^{+}$, TRA $-1-81^{+}$, SSEA $^{+}$ & {$[8,61,62]$} \\
\hline Renal & SSEA $1^{+}, \mathrm{CD}_{105^{+}}$ & {$[63,64]$} \\
\hline Ovary & $\mathrm{CD}_{13} 3^{+}, \mathrm{CD} 117^{+}, \mathrm{DLL}^{+}, \mathrm{CD}_{4} 4^{+\mathrm{a}}, \mathrm{CD} 24^{+}, \mathrm{ALDH}^{\text {high }}$ & {$[65-67]$} \\
\hline Colorectal & $\mathrm{CD}_{2} 6^{+}, \mathrm{LGR}^{+}, \mathrm{DLL}^{+}, \mathrm{CD}_{4} 4^{+\mathrm{a}}, \mathrm{CD}_{133^{+}}, \mathrm{EpCAM}^{\text {high }}, \mathrm{ABCG}^{+}, \mathrm{ALDH}^{\text {high }}$ & {$[68,69]$} \\
\hline
\end{tabular}

${ }^{a}$ These markers expressed on both Cancer stem cells and normal tissue cells 


\section{NK cells as the ancient warriors against cancer}

The peripheral blood NK cells are divided into two subsets of CD56 $6^{\text {bright }}$ and CD56 ${ }^{\text {dim }}$ during the developing stages and based on the expression of this receptor, and after education and maturation (Fig. 2A, B), they are distributed into different organs (Fig. 2B) based on their unique characteristics [16]. CD56 ${ }^{\text {bright }}$ $\mathrm{CD} 16^{\text {neg }} \mathrm{NKG} \mathrm{A}^{+} \mathrm{KIR}^{\text {neg }} \mathrm{NK}$ cells are more immature than $\mathrm{CD}_{56} 6^{\mathrm{dim}} \mathrm{NKG} 2 \mathrm{~A}^{ \pm} \mathrm{KIR}^{+} \mathrm{CD} 16^{+}$NK cells. Moreover, CD56 ${ }^{\mathrm{dim}} \mathrm{NKG}^{\mathrm{A}} \mathrm{A}^{ \pm} \mathrm{KIR}^{+} \mathrm{CD} 16^{+} \mathrm{NK}$ cell subset includes more mature NK cell subset represented by $\mathrm{CD}_{57}{ }^{+} \mathrm{KIR}^{+} \mathrm{NKG} \mathrm{A}^{-} \mathrm{NKG}^{+} \mathrm{C}^{+}$adaptive NK cells [17, 18]. IL-2, IL-4, IL-7, IL-10, IL-12, IL-18, IL-21, type I and type II IFN, and TGF- $\beta$ are the cytokines which play essential roles in NK cells maturation (Fig. 2B) [19-21]. The gun-house of NK cells is packed with granular weapons called Perforin and Granzyme which are released in the synaptic space between NK cells and their target, destroying the target cells (Fig. 2B, C) [22]. Due to their immunological mediating role, these cells form a desirable connection between the innate and adaptive immunity responses to cancer cells (Fig. 2C) $[23,24]$. NK cell capability to destroy and eliminate the target cells depends on the balance of its activating and inhibitory signals $[25,26]$ i.e. the ligands expressed on the target cells interact with the NK cell surface activating and inhibitory receptors and trigger the activating or inhibitory signals, so NK cells are not controlled by antigen specificity [26-29].
NK cells functional mechanism is based on the identification of MHC class I (HLA class I) molecules as ligands for NK cell receptor group of killer cell immunoglobulinlike receptors (KIRs) that are able to bind four types of MHC class I in human (HLA-A, HLA-B, HLA-C and HLA-G). MHC class I molecules expressed on the surface of healthy cells can act as inhibitory ligands in binding to their receptors on the surface of NK cells and as a result cause the self-tolerance of NK cells. The expression of MHC molecules in abnormal and tumor cells is decreased which reduces the induction of inhibitory signals in NK cells. As a result, the balance of signals shifts to NK cell activation and elimination of target cells.

Moreover, cancer cells, especially CSCs, express low/ no levels of MHC class I (the missing self-hypothesis), so they are highly susceptible to destruction by NK cells [9]. Some CSCs, in addition to low MHC class I expression levels, express high levels of NK cell activating markers and are therefore more susceptible to be killed by NK cells [30-32]. The expression of several CSC markers (Table 2) such as CD24, CD44, CD133 and ALDH can increase the elimination susceptibility of these cells by the activated NK cells through stimulation of NK activation markers such as MICA/B, Fas and Death receptors $[8,11,32,33]$.

The previous studies on melanoma, colorectal and glioblastoma have shown that NK cells are more likely to target CSCs than non-CSCs in heterogeneous solid tumor populations without any pharmacological pretreatment

\footnotetext{
(See figure on next page.)

Fig. 1 Cancer stem cells targeting. There are Different approaches for targeting cancer stem cells that can be used in a variety of cancers such as: (A) CSC niches: various types of cells and growth factors involving endothelial cells, immune cells, cancer associated fibroblasts (CAFs), various growth factors, and cytokines can be contained in the niche which provide a suitable microenvironment for tumor growth. Severe hypoxia and increased angiogenesis in the tumor microenvironment would cause a CSC niche to be formed near blood vessels. Along with these components, environment shifts, such as hypoxia, and pH have been introduced to contribute to the CSC niche. One of the important features of TME is low oxygen levels, referred to as hypoxia which turns out to maintain the stemness and thus malignancy of CSCs and finally promote tumor survival and metastasis. in response to hypoxia, the expression of the hypoxia-inducible factors (HIF1a, HIF-2a) are increased which can result in tumor malignancy. B Signaling pathways: One of the emerging targets for cancer treatment is the signaling pathways that regulate CSCs maintenance and survival. At present the Wnt, Notch, and Hh signaling pathways, as well as the TGF- $\beta$, JAK-STAT, PI3K, and NF-KB signaling pathways are the main signaling pathways which often interact with each other in CSCs during tumor development. Targeting the Wnt pathway has been proved to be difficult but noticeable progress has been made in early clinical trials of Notch and Hh pathway inhibitors. C Cell surface markers: targeting CSC surface markers is a potential CSC therapeutics approach and CD44 is one of the most commonly used and established CSC biomarkers which is a cell-surface extracellular matrix receptor. Many studies have introduced CD44 antibody therapy as the major anti-CSC approach. Another well-known CSC marker in several tumors such as glioblastoma, hepatocellular and colon cancers is CD133 which is a transmembrane glycoprotein. CD133 + CSCs have been proved to be resistant to chemotherapy and radiotherapy due to their lower proliferation, slower cell cycle, anti-apoptotic genes and higher expression of DNA repair. EPCAM has been discovered to be a CSC marker in solid tumors and is correlated with all CSCs characteristics. There is a significantly high frequency of tumor-initiating cells in EpCAM +/CD44+/CD24- population in breast cancer. D Therapeutics molecules and (E) differentiation therapy: Metformin, salinomycin, DECA-14, rapamycin, Oncostatin M (OSM), some natural compounds, oncolytic viruses, microRNAs, signaling pathway inhibitors, TNF-related apoptosis inducing ligand (TRAIL), interferon (IFN), telomerase inhibitors, All-trans retinoic acid (ATRA) and monoclonal antibodies have recently been shown to suppress CSCs self-renewal in vitro and in vivo. A combination of these agents and conventional chemotherapy drugs can be used to dramatically hinder tumor growth, metastasis and recurrence; and (F) overcoming drug resistance in CSCs: Drug efflux leads to decreased intracellular drug concentration in CSCs through multi-drug resistance (MDR) transporters. Overexpression of ABCG2 which is one of the subfamilies of the ATP-binding cassette (ABCA-G) transporters is a major mechanism of chemoresistance in CSCs cells. The fourth generation of inhibitor drugs is in progress [4, 9-13]. CSCs cancer stem cells, DLL delta-like ligand, ATRA all-trans retinoic acid, OSM oncostatin M, BMPs bone morphogenetic proteins, CDF difluorinated curcumin, ALDHs aldehyde dehydrogenases, DEAB diethylaminobenzaldehyde, HIF hypoxia-inducible factors
} 


\section{Target the HIF pathway \\ PX-478}

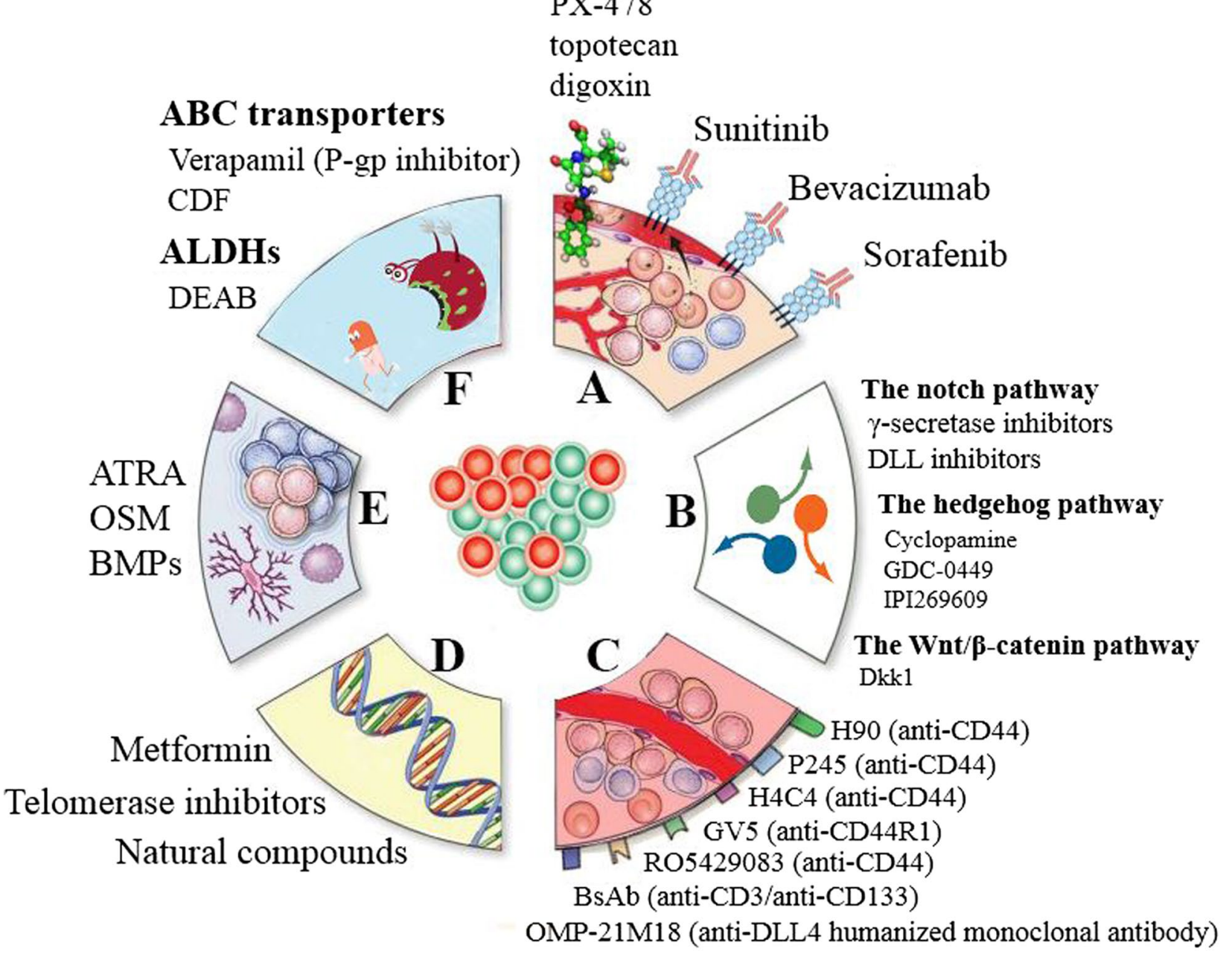

Fig. 1 (See legend on previous page.)

\section{(See figure on next page.)}

Fig. 2 NK cell, from development to Functioning. A The pathway of NK cell generation and development; NK cells are derived from common lymphoid progenitor (CLP), and then enter the NK cell precursors (NKP) stage that express IL-7R and IL-2Rß 2Rß and IL-15 which play crucial roles in NK cells differentiation from CLPs to mature NK cells. These cells then express NKR-P, CD2, CD56, CD94 and KIRs and go through maturity and get ready for function. Mature NK cells also gain functional competence, expressing lytic molecules and cytokines such as Perforin, Granzyme A/B and IFN-ץ. B NK cell educating and function; NK cells disappear from blood either by entering tissues, predominantly the spleen and the liver or through cell death. CD56 bright NK cells proliferate fast, but die relatively slowly which suggests that proliferating CD56 bright cells differentiate into CD56 ${ }^{\mathrm{dim}}$ NK cells in vivo. The peak of the effector NK cell expansion occurs at around 7-8 days after activation, regardless of the precursor frequency of antigen-specific NK cells, however it is difficult to detect memory NK after 4-5 months although they still exist. NK cells depict three mechanisms for their function on the target cells in 3 different pathways; 1. Missing-self in which the inhibitory receptors of MHC-I molecules are involved, and the cells are lysed in the down-regulation of MHC class I molecules, 2. Induced self-ligands in which NK cell activating receptors can detect stress molecules that are overexpressed by tumor cells, and ultimately lysing the target cell, 3. Antibody-dependent NK cell-mediated cytotoxicity in which specific antibodies of tumor antigens are binding to CD16 and subsequently cause the target cell to lyse (21, 22). C NK cells can play modulatory role in the immune system against tumor and infected cells, and affect $T$ cells and macrophages and prepare them to serve, and also have a significant contribution to the process of maturation of dendritic cells. HSCs hematopoietic stem cells; mNK cell, mature NK cell 
A

B
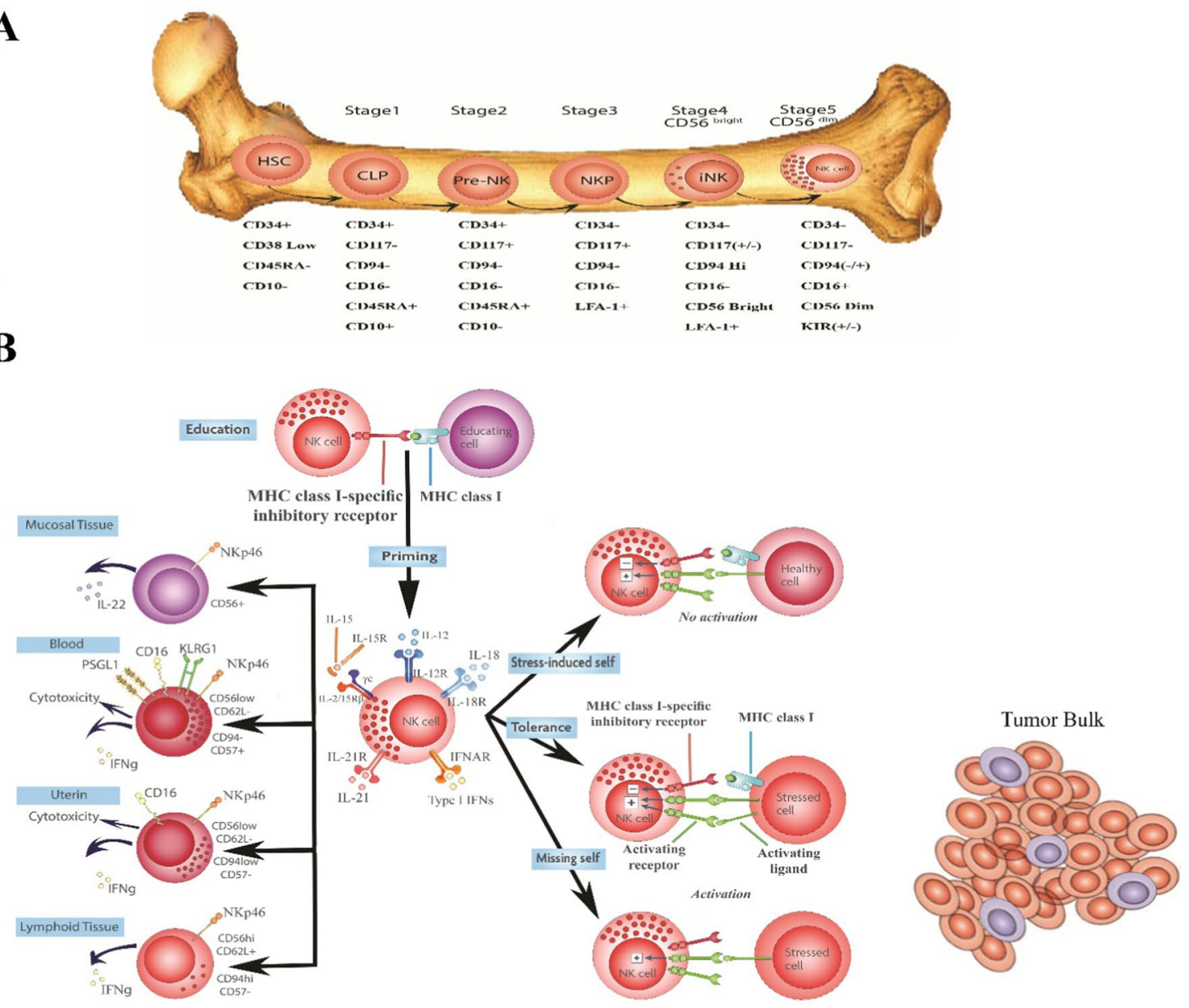

C

C

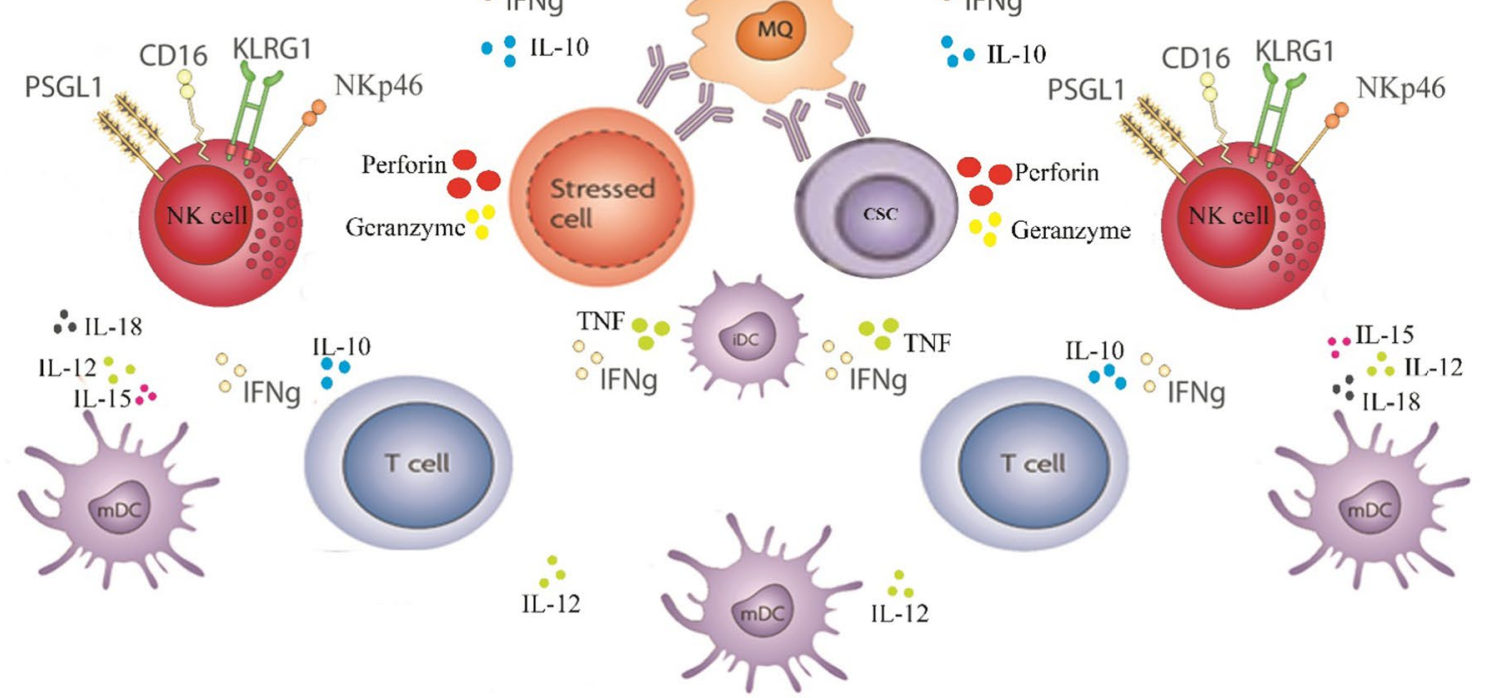

Fig. 2 (See legend on previous page.) 
[30, 31, 76]. Another study on CD44+CD24- human breast CSCs demonstrated that these cells were sensitive to NK cells activated by Interleukin 15 and 2, and these effects were due to the increased expression of NKG2D ligands, ULBP1, ULBP2 and MICA, on these CSCs [77, 78]. CSCs having low MHC-I and beta microglobulin levels can facilitate the escape from immune system attack, considering that downmodulation of MHC-I expression on CSCs can facilitate the escape from cytotoxic T lymphocyte-mediated immune responses. CTL-mediated killing is based on self-MHC molecule that is expressed on the antigen-specific target cells that must be recognized by T cell receptor (TCR), therefore the histocompatibility complex (MHC) restriction is a major limitation of this process. On the contrary, NK cells can kill tumor cells that do not express HLA-I molecules but NK cell therapy has its own challenges as CSCs can escape from NK cells killing response via some alternative pathways which are mentioned accordingly $[36,79]$.

A study on the immunogenicity of $\mathrm{CD} 133+$ brain tumor stem cells (BTSCs) has shown a downregulation in MHC class-I (MHC I) expression or NK cell activating ligands on the majority of CD133 + cells, which may make these cells resistant to the adaptive and innate immune surveillance [79]. However, both CD133and CD133 + cells of melanoma, were vulnerable to IL-2 activated allogenic NK cells and responded to the DNAM-1 ligands Nestin-2 and PVR [80]. High levels of anti-apoptotic proteins such as Bcl-2, Bcl-xL and surviving proteins protect CSCs from NK cells and cytotoxic $\mathrm{T}$ cells responses [81]. The data obtained from another study focusing on MICA and MICB (MHC class I-related chain A and B) in TME (tumor microenvironment), revealed that these stimulatory NKG2D receptor ligands are downregulated due to the aberrant expression of oncogenic miR-20a in human breast CSCs and ultimately lead to the escape of these CSCs from NK cell killing [28, 82, 83]. Breast CSCs having a $\mathrm{CD} 44^{\text {high }} / \mathrm{CD} 24^{\text {low }}$ phenotype can also escape the effect of NK cells by eliciting resistance to trastuzumabmediated antibody-dependent cell-mediated cytotoxicity (ADCC) [83]. Colon CSCs secrete high levels of
IL-4 which is a cytokine promoting drug resistance and inhibiting the immune response to tumors [31, 42]. Some CSCs associated with certain types of cancer resist the NK cells killing by not expressing NK cell activating ligands such as NKG2D, NKp30 and NKp44 and also increasing the expression of inhibitory ligands such as CD94/NKG2A [79, 83]. The previous studies have shown that these expression changes in surface markers and ligands associated with NK cell receptors can reduce the expression level of CD16 during NK cells development and consequently reduce the cytotoxic ability by interaction with CSCs. In this phase, NK cells are in a state called "split anergy" in which only the production of interferon-gamma (IFN- $\gamma$ ) and tumor necrosis factor-alpha (TNF- $\alpha$ ) is maintained $[33,84,85]$. This functional state is critical for tumor differentiation and the functional NK cell inactivation $[33,86,87]$. It is important to note that the activity of NK cells is inhibited by the immunosuppressive factors such as TGF- $\beta$, IL-6, IL-8, IFN- $\gamma$, MICA, B released in TME [88] and the differences between the CSCs and other tumor cells secretomes may also inhibit cytotoxic NK cells more strongly [8].

To develop NK cell-based therapies, it is important to find appropriate sources of these cells that minimize cell number limitations, immunological complications, and HLA Donor-Recipient matching [89-91]. There are several sources of NK cell including peripheral blood (PB), umbilical cord blood (UCB) [92], bone marrow (BM) and cell lines [93]. Deriving NK cells from PBMC, hESC and iPSC sources was a revolution which wiped out the worries about the low number and purity of NK cells forever [94]. The use of PBMC, hESC and iPSC sources as homogeneous and off-the-shelf sources for NK cells would open up the possibility to create clinical cell banks available to patients on demand and these features can also provide an unlimited source of genetically engineered NK cell products and the emergence of new tool called CAR-NK for cancer treatment [95-98]. The effects of different types of NK cell sources in clinical evaluation for metastatic cancers have been compared and the results are depicted in Table 3.

Table 3 Comparison of the effects of different types of NK cell immunotherapies for targeting malignancies

\begin{tabular}{lll}
\hline NK source & Advantages & Disadvantages \\
\hline Autologous NK cells & $\begin{array}{l}\text { Universal } \\
\text { Safe }\end{array}$ & Low efficacy \\
Allogenic NK cells & Highly effective against some malignancies & no standard protocols or products \\
CAR NK cells & $\begin{array}{l}\text { Highly potentiate NK cell antitumor activity; more efficiency and safer } \\
\text { than CART cells }\end{array}$ & Difficult manipulate Difficult expansion \\
NK cell lines & $\begin{array}{l}\text { Unlimited } \\
\text { Homogeneous well-defined highly active population low cost }\end{array}$ & Low efficacy safety concerns need to be irradiated \\
\hline
\end{tabular}


Therefore, the mechanisms described can be used to target cancer stem cells and provide alternative approaches to design CAR-NK cells so as to produce desirable NK cells that promote optimal cytotoxicity against cancer stem cells as well as being highly resistant to inactivation mechanisms.

\section{CAR NK cell as a novel tool to target CSCs}

The design and use of CARs to reach PBMC, hESC and iPSC- derived NK cells is based on genetic engineering and modifying and using a variety of cytokines, growth factors, feeder's layer and monoclonal antibodies [95]. CAR-immune effector cells have the ability to recognize the tumor associated antigens (TAAs), and subsequently eliminate the target cells through inducing the cytotoxic factors such as perforin and granzyme [99]. To date, five generations of CAR have been introduced, and its construct is based on three regions, including the extracellular domain consisting of a single-chain variable fragment (scFv), a linker that is flexible and attached through a spacer to the transmembrane domain and an intracellular signaling domain of immunoreceptor tyrosine-based activation motifs (ITAM) TCR or a cytoplasmic domain of other activating receptors. The first generation of CARs consisted of a single-chain variable fragment $(\mathrm{scFv})$ recognizing the tumor surface antigens, and an immunoreceptor tyrosine-based activation motif (ITAM) which is usually $\mathrm{CD} 3 \zeta$ chain as an intracellular signaling domain [100]. The second and third generations of CAR platforms are being used According to the dual-signal model activation. These structures introduced CD28, CD134 (OX40), CD137 (4-1BB) and 2B4 and other costimulatory molecules, pursuing the goal of increasing cytotoxicity [101]. The fourth and fifth generations are also based on the second generation but replacing the additional costimulatory molecule of the third generation with protein inducers (IL-12, IL-18) and IL-2 receptor $\beta$-chain domain in the fourth generation and STAT3 binding site in the fifth generation to overcome the immunosuppressive tumor microenvironment. Therefore, these approaches provide the three signals that are required for CAR-modified cell activation [102]. Despite obtaining successful results in CAR-T cell therapy against tumor cells, CAR-NK cells offer many advantages for cancer immunotherapy [103] which are mentioned in Table 4.

One of the most significant advantage of NK cells is the limited lifespan after activation which eliminates the need for the presence of the suicide gene as a safety key in the CAR structure [104].

As of April 2021, twenty-three studies have been submitted to Clintrials.gov to evaluate the safety and efficacy of CAR-NK cells in cancer patients (Table 5).
The studies mentioned in Table 5 used the approaches of overcoming the major challenges of achieving functional NK cells against tumors, especially the solid tumors (Fig. 3). These challenges are classified into the following groups:

\section{Providing NK cells}

There are still many potential challenges in providing NK cells from the desirable sources as well as maintaining the NK cell expansion in the recipients' body. Allogeneic NK cells are widely used in clinical trials today, however, after development which has the possibility of infusion contamination with $\mathrm{T}$ or $\mathrm{B}$ cells in the expanded NK cell preparation, undesirable immune responses can be induced in the recipient, such as GVHD or post-transplant lymphoproliferative disease [93]. As mentioned, NK cells have a short life after gaining their killing function. Therefore, maintaining the number of functional NK cells is another challenge in immunotherapy with NK cells.

The use of CAR-NK cells expressing IL-2 and IL-15 is suggested as an applied strategy for overcoming the mentioned challenges. Liu et al. used a single infusion of CD19-CAR/IL15 + CB-NK cells in Raji lymphoma mouse models with the approach of increasing the function and survival of NK cells which was successful in controlling the tumor progression [105]. MD Anderson Cancer Center has run a dose escalation study phase I/ II of umbilical cord blood-derived CAR-engineered NK cells in conjunction with lymphodepleting chemotherapy in Relapsed/Refractory B-Lymphoid malignancies (NCT03056339) with the aim of investigating the highest tolerable dose of CAR-NK cells for the patients with relapsed or refractory B-cell lymphoma or leukemia. In this study, CAR-NK (iC9/CAR.19/IL15transduced CB-NK cells) cells were used after chemotherapy, as a result of which some improvements were observed in the disease in stem cell transplant patients with relapsed or refractory (has not responded to treatment) B-cell lymphoma or leukemia. A pilot study of NKG2D-ligand targeting CAR-NK cells in metastatic solid tumors patients is ongoing in its first phase in Guangzhou China in which some of patients are going to receive Interleukin-2 (IL-2) subcutaneously following the infusion of CAR-NK cells to support the in vivo survival of CAR-NK cells (NCT03415100). Another study is going to use engineered NK-92 as specific CARpNK cell to target relapsed/refractory CD33 + AML in which NK92 cells are engineered to contain anti-CD33 attached to TCR $\zeta, \mathrm{CD} 28$ and 4-1BB signaling domains (NCT02944162). In another ongoing study anti-CD19 attached to TCR $\zeta, \mathrm{CD} 28$ and 4-1BB signaling domains is being used for generating allogenic CAR-NK cells in 
Table 4 The comparison of CAR-T cells with CAR-NK cells

\begin{tabular}{|c|c|c|}
\hline & CAR-NK & CAR-T \\
\hline Source & Various & Limited \\
\hline $\begin{array}{l}\text { Expression of surface receptor (Ag-specific } \\
\text { receptor) }\end{array}$ & Not required (germ line-encode) & Required (rearranged Ag-specific) \\
\hline Prior sensitization & Not required & Required \\
\hline Collection & Leukopheresis & Leukopheresis \\
\hline Preparation & $\begin{array}{l}\text { Autologous: } \mathrm{CD} 56^{+} \text {Enrichment } \\
\text { Allogeneic: MHC-matched donor selection or } \\
\text { alloreactive T-cells depletion }\end{array}$ & $\begin{array}{l}\text { Activation of cells with anti-CD3/CD28 beads } \\
\text { Allogeneic donor: MHC match required }\end{array}$ \\
\hline Expansion & $\begin{array}{l}\text { engineered feeders required (example: K562 } \\
\text { cells expressing IL-15 and TNFSF9) plus IL-2 (in } \\
\text { flasks, bags or bioreactors) }\end{array}$ & Flasks, bags or wave expansion system \\
\hline Transduction & $\begin{array}{l}\text { Low transfection efficiency even with viral } \\
\text { vectors }\end{array}$ & $\begin{array}{l}\text { Desirable transfection efficacy } \\
\text { Ex: Lentiviral systems transduce about 1/3 of T } \\
\text { cells }\end{array}$ \\
\hline Cytotoxic mechanisms & $\begin{array}{l}\text { Multiple receptors can trigger CAR-independent } \\
\text { and FcR-dependent cytotoxicity }\end{array}$ & $\begin{array}{l}\text { CAR-restricted killing } \\
\text { In case of antigen loss on tumors, CAR-expressing } \\
\text { T cells become ineffective }\end{array}$ \\
\hline Escaped tumor and infected cells recognition & Yes & No \\
\hline Clinical results & Proof of clinical benefit pending & Phase II studies have shown clinical benefit \\
\hline In vivo functionality & No need for suicide gene & $\begin{array}{l}\text { Suicide genes are required to control life span } \\
\text { in vivo }\end{array}$ \\
\hline HLA expression-related recognition & Dependent & Independent \\
\hline GVHD & Low/no & High/yes \\
\hline Cytokine-induced killer cells & No & Yes \\
\hline Toxicity & Low & High (neurotoxicity) \\
\hline Safety & High/low safe & Low/no safe \\
\hline Side effects & Limited life span in patients & $\begin{array}{l}\text { "off target" effect prolonged Survival period in } \\
\text { patient's circulation } \\
\text { CRS } \\
\text { MQ activation syndrome } \\
\text { Hemophagocytic Lymphohistiocytosis (hlh) }\end{array}$ \\
\hline Off-the-shelf availability & Present & Missing (preparation required for each patient) \\
\hline Cost & Cost benefit & Expensive \\
\hline
\end{tabular}

treating patients with CD19 positive relapsed or refractory leukemia and lymphoma (NCT02892695).

\section{NK trafficking and infiltrating into tumor sites}

Migration and localization of NK cells in the tumor sites and their number infiltrated into tumor is another major challenge for CAR-NK therapy. To overcome the anatomical barriers, different injection approaches such as local injection, intra-peritoneal injection, and focused ultrasound-guided delivery can be used [106]. HER2 has been shown to be up-regulated in several solid tumors including brain, breast, colon, and ovary making it a desirable target for CAR-NK cells therapy [96-98]. In a preclinical study, anti-HER2 CAR-NK-92 cells were delivered into the brain of mice with metastatic breast cancer using focused ultrasound [107].

To increase the infiltration and homing capacity, CARs can be used that express chemokine receptors (CCRs) compatible with chemokine CC (CCL) ligands of tumor cells, for example, CXCR2-expressing NK cells show significant migration to tumors expressing CXCR2 ligands $[108,109]$. In the treatment of CXCL12/SDF-1 $\alpha$ secreting glioblastoma cells, anti-EGFRvIII CAR NK cells were used with overexpression of CXCR4 and the results showed an increase in chemotaxis towards these tumor cells, complete tumor remission in a number of mice, and an increased overall survival [110].

Modification of TME by oncolytic viruses can induce an inflammatory immune response, followed by an enhanced immune cell trafficking [111]. In a preclinical study, the combination of EGFR-CAR NK-92 cells with oHSV-1 in mice with breast cancer tumor cells in the brain resulted in more efficient removal of the tumor cells in the brain as well as the increased survival [112].

The use of specific markers of a particular type of cancer (mentioned in Table 2) is also one of the approaches that have been considered in some studies today among which we can mention NCT03692637 study, targeting 
Table 5 CAR-NK cells in clinical trials

\begin{tabular}{|c|c|c|c|c|c|c|c|}
\hline Tumor type & Condition or disease & Origin of NK cell & Target & Status & Phase & Country & Clinical trial ID \\
\hline \multirow{14}{*}{$\begin{array}{l}\text { Hema- } \\
\text { tological } \\
\text { malignancy }\end{array}$} & B-ALL & Haploidentical PB-NK & CD19 & Recruiting & $\|$ & Singapore & NCT01974479 \\
\hline & B-ALL & Haploidentical PB-NK & CD19 & Completed & I & USA & NCT00995137 \\
\hline & Lymphoma and leukaemia & NK-92 & CD7 & Recruiting & $|/| \mid$ & China & NCT02742727 \\
\hline & Lymphoma and leukaemia & NK-92 & CD19 & Recruiting & $|/| \mid$ & China & NCT02892695 \\
\hline & Refractory B-cell lymphoma & Unknown & CD19 & Not recruiting & Early I & China & NCT03690310 \\
\hline & $\begin{array}{l}\text { Relapsed or Refractory B Cell Non- } \\
\text { Hodgkin Lymphoma }\end{array}$ & Unknown & CD19 & Not recruiting & Early Phase 1 & China & NCT04639739 \\
\hline & $\begin{array}{l}\text { Relapsed and refractory B cell malig- } \\
\text { nancies }\end{array}$ & Unknown & & Recruiting & $|/| \mid$ & China & NCT04747093 \\
\hline & Refractory B-cell lymphoma & Unknown & CD19/CD22 & not recruiting & Early I & China & NCT03824964 \\
\hline & AML & NK-92 & CD33 & Completed & $|/| \mid$ & China & NCT02944162 \\
\hline & $\begin{array}{l}\text { Lymphoma and leukaemia (relapsed/ } \\
\text { refractory B-cell malignancy) }\end{array}$ & Umbilical cord blood & CD19 & Recruiting & $|/| \mid$ & USA & NCT03056339 \\
\hline & Refractory B-cell lymphoma & Unknown & CD22 & Not recruiting & Early I & China & NCT03692767 \\
\hline & Lymphoma and leukaemia & Umbilical cord blood & CD19 & Withdrawn & $|/| \mid$ & USA & NCT03579927 \\
\hline & relapsed/refractory multiple myeloma & NK92 & BCMA & Recruiting & $|/| \mid$ & China & NCT03940833 \\
\hline & B-cell lymphoma, CLL & iPSC (FT596) & CD19 & Recruiting & I & USA & NCT04245722 \\
\hline \multirow[t]{9}{*}{ Solid tumor } & Metastatic solid tumor & PB-NK & NKG2DL & Recruiting & I & China & NCT03415100 \\
\hline & Glioblastoma & NK-92 & HER2 & Recruiting & । & Germany & NCT03383978 \\
\hline & Non-small cell lung cancer & NK-92 & - & Recruiting & । & China & NCT03656705 \\
\hline & Solid tumor & NK-92 & $\mathrm{ROBO} 1$ & Recruiting & $|/| \mid$ & China & NCT03931720 \\
\hline & Solid tumors & NK-92 & $\mathrm{ROBO} 1$ & Recruiting & $|/| \mid$ & China & NCT03940820 \\
\hline & Pancreatic cancer & NK-92 & ROBO1 & Recruiting & $|/| \mid$ & China & NCT03941457 \\
\hline & Epithelial ovarian cancer & PB-NK & Mesothelin & not recruiting & Early 1 & China & NCT03692637 \\
\hline & Castration-resistant prostate cancer/ & PB-NK & PSMA & Not recruiting & Early I & China & NCT03692663 \\
\hline & Solid tumor & NK-92 & $\mathrm{MUCl}$ & Recruiting & $|/| \mid$ & China & NCT02839954 \\
\hline
\end{tabular}

epithelial ovarian cancer by anti-mesothelin CARNK cells and another study (NCT03692663) using antiPSMA CAR-NK cells in patients with castration-resistant prostate cancer.

\section{Lack of NK function in the tumor microenvironment}

Tumor cells recruit neutrophils, macrophages, Tregs and immunosuppressive myeloid suppressor cells (MDSCs) in TME which produce factors such as TGF- $\beta$, IL-10, PD-1 and arginase to escape the immune responses providing a strong immunosuppressive environment for tumor growth [113]. Several strategies have been reported to preserve the function of NK cells in vivo and minimize the effects of the mentioned inhibitory factors. For example, the use of TGF- $\beta$ kinase inhibitors with NK cells can maintain the potential for cytotoxicity and expression of NKG2D and CD16 activating receptors [114]. To increase the antitumor activity in NK-92 cells, a hybrid CARs with an extracellular TGF- $\beta$ receptor domain linked to an intracellular NKG2D domain as well as knocking down SMAD3 was used which lead to improving the function of NK cells against the solid tumors $[115,116]$. Also, to increase the cytotoxicity of NK cells against tumor cells, a narrow-spectrum histone deacetylase inhibitor called Entinostat was used, which increased MICA expression on tumor cells and NKG2D expression in primary NK cells, even in the hypoxic environment [117]. NK cells in hypoxic environment would face a downregulated expression of activating receptors such as NKp30, NKp46, NKp44 and NKG2D, and a suitable environment is provided for tumor progression due to inducing metabolic disturbance, increasing angiogenesis and expression of tumor growth factors $[13,113]$.

CD73 induces the expression of arginase under hypoxic conditions and inhibits NK cell functions. In a preclinical study on mouse models with lung cancer, CD73 inhibition was used in combination with NKG2D-CAR-NK. CD73 inhibition in the tumor cells expressing NKG2D caused an increased NKG2D-CAR-NK cells infiltration into the tumor site and an improved anti-tumor response [118].

The expression of checkpoint proteins on tumor cells such as PD-1, CTLA-4, LAG3, and TIGIT can provide immune surveillance evasion. Therefore, the use of checkpoint protein blockers in the CARs structure can provide the possibility of an improved cytotoxic function 


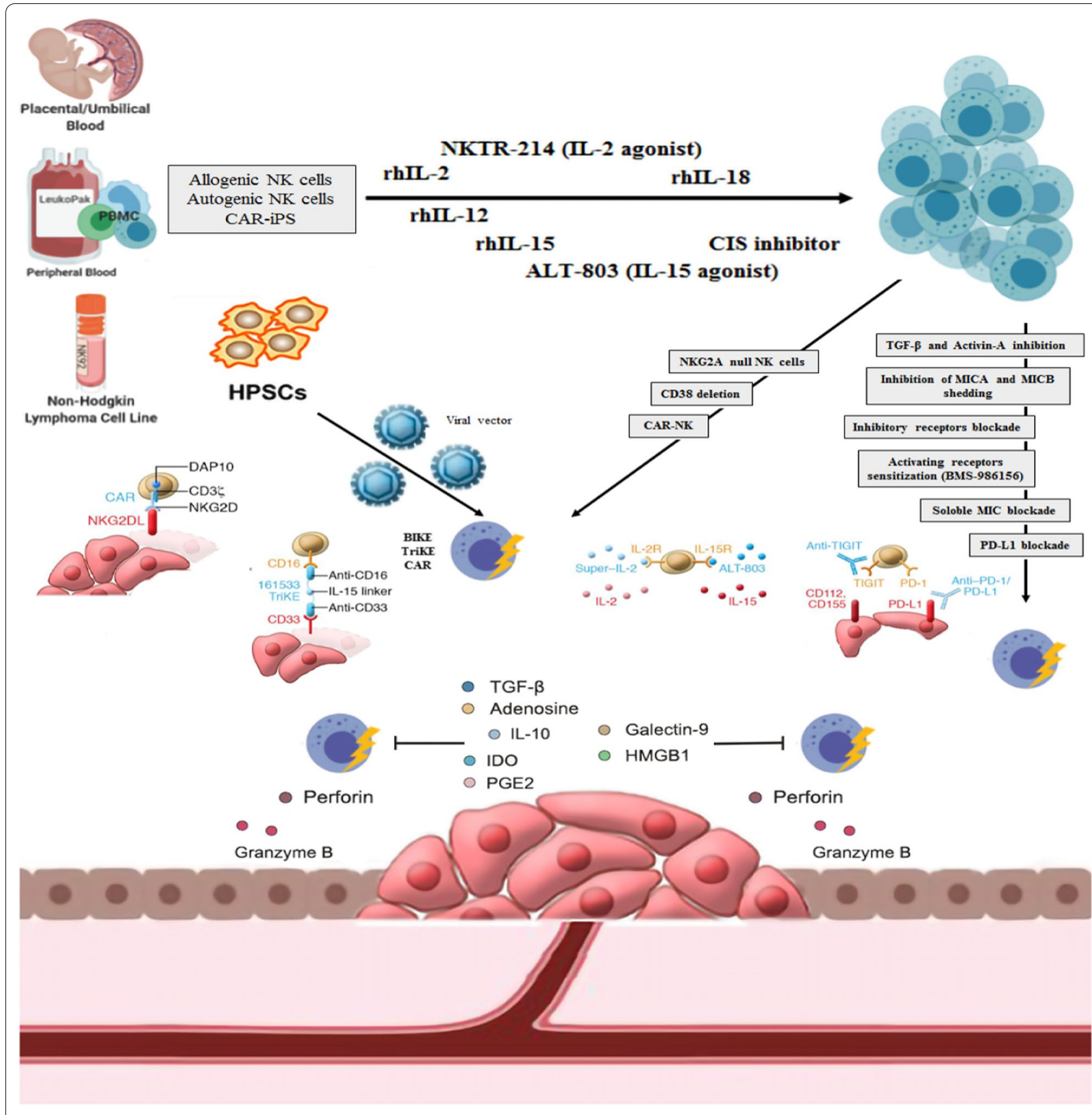

Fig. 3 Strategies for achieving functional NK cells against tumor cells

[119]. The combination of PD-L1-CAR-NK-92 cells with high-affinity CD16 and IL-2 has high levels of perforin and granzyme expression against human cancer cell lines including breast, lung, and gastric cancers [119-124].

\section{The efficacy of CARs transduction methods}

Today, two approaches are used for the transduction of CARs construct including viral and non-viral based methods. The efficacy of transduction methods is one of the challenges to be considered in using CAR-modified NK cells [125]. viral vectors (Lentivirus and Retrovirus) applied for CAR transduction have high potential and efficacy in the clinical uses while having some limitations such as the risk of inducing mutagenesis, which is not desirable for human clinical use [100, 125, 126]. The use of non-viral methods such as mRNA electroporation, also has its own limitations such as the lack of integration of transcripts into the genome because of 
its short-expression time [127]. The quantity of mRNA used are also critical in clinical applications which should be compensated by multiple infusions for the transient expression of CAR proteins [127, 128]. The efficiency of viral and non-viral transduction methods has been compared with each other in Table 6.

\section{Tumor antigen heterogeneity}

Finding a target antigen on the surface of a tumor cell that is very uniformly expressed is the most important step in designing CARs. Clonal evolution and downregulation of TAA expression can cause significant differences in TAA expression between the single-cell clones, allowing tumors to evade the immune surveillance. Most TAAs are expressed by cells not only in tumor especially solid tumors, but also in vital organs, making it impossible to avoid "on-target, off-tumor" effects [100, 113, 119, 137]. Using bispecific CARs which have the ability to recognize two different antigens and are activated by the binding of both antigens provides the possibility of relative overcoming of this problem [100, 138, 139]. BCMA-CAR-NK 92 cells are being used in the relapsed and refractory multiple myeloma patients with BCMA (B-cell maturation antigen) expression in Suzhou Hospital Affiliated to Nanjing Medical University with the purpose of enabling NK-92 cells by CARs to recognize and kill MM cells through targeting BCMA (NCT03940833). Another study in phase 1 and 2 of clinical trials is also being conducted by the same group focusing on the anti-tumor responses of BiCAR-NK/T cells on patients with solid tumors without any conditioning chemotherapeutic regimen
(NCT03940820). Three studies focusing on targeting ROBO1 by BiCAR-NK/T cells (ROBO1-CAR-NK/T cells) are ongoing in China and are intended to investigate the effects of CAR-NK cells on pancreatic cancer (NCT03941457), solid (NCT03940820) and malignant (NCT03931720) tumors.

Studies on targeting cancer stem cells in the field of research are numerous, but limited in clinical trials. Therefore, it seems that the development of the novel therapeutic modalities such as the combination of CAR engineering with CRISPR-Cas9 gene editing in primary NK cells may lead to successful clinical trials.

\section{Conclusion}

NK cells with their specific characteristics against tumor cells have opened up a new world in treating and fighting against cancer [140]. These cells have shown remarkable anti-tumor function against hematologic cancers, but their function against solid tumors has remained unclear [141]. However, the significant point about these cells is that they can be used in many advanced malignancies for adoptive cell therapy $[4,11$, 140]. CAR technology in this scenario, has been proved to be very helpful. Through this technology, the resulting NK engineered cells can both recognize tumor cells and use their killing ability against them. In addition, if we arm the engineered cells against cancer stem cells, we can succeed in removing them. The NK cells, as warriors in the cancer cells dark world, have emerged and attracted much attention and that is why many studies on cancer NK cell therapy are ongoing today.

Table 6 comparison of the efficiency of Viral and non-viral transduction methods

\begin{tabular}{|c|c|c|c|c|c|}
\hline Source of NK cells & & Transduction method & Transduction vector & $\begin{array}{l}\text { Transduction } \\
\text { efficiency (\%) }\end{array}$ & References \\
\hline \multirow[t]{4}{*}{ Primary cells } & & Viral-based & Lentivirus & $16-80$ & {$[111,118]$} \\
\hline & & & retrovirus & $27-75$ & [119] \\
\hline & & Non-viral based & mRNA transfection & $10-85$ & {$[120,121]$} \\
\hline & & & Trogocytosis & $24-47$ & [122] \\
\hline \multirow[t]{6}{*}{ Cell lines } & NK-92 & Viral-based & Lentivirus & $15-26$ & {$[121,123,124]$} \\
\hline & & Non-viral based & mRNA transfection & 56 & {$[121]$} \\
\hline & & & PiggyBac & 84 & [111] \\
\hline & YTS & Viral-based & Lentivirus & $30-98$ & [111] \\
\hline & LNK & & & $30-40$ & [124] \\
\hline & DERL7 & & & $30-40$ & \\
\hline \multirow[t]{2}{*}{ UCB-derived Cells } & & Viral-based & Lentivirus & $12-73$ & [121] \\
\hline & & & retrovirus & $49-67$ & {$[125,126]$} \\
\hline \multirow[t]{2}{*}{ iPSCs } & & Non-viral based & pKT2-mCAG-IRES & - & {$[127,128]$} \\
\hline & & & PiggyBac & & \\
\hline
\end{tabular}




\section{Future perspective}

Recent advances in gene editing technology have let us imagine its potential applications for the creation of novel CAR-NK cells with anti-tumor activity having limited cytotoxicity to normal tissues in clinical trials. The novel strategies, such as CRISPR-Cas9 genetic modifications as innovative methods can introduce alternative platforms for overcoming the current limitations of NK cell-based therapy including the fact that the positive signal induced by CAR is only partially inhibited by the negative signal generated by KIRs or NKG2A in allogenic transplantations.

\section{Acknowledgements}

We want to thank all the colleagues for their critical discussion regarding the manuscript.

\section{Authors' contributions}

AS: conception and design, collection and/or assembly of data, manuscript writing, discussed the results and commented on the manuscript. JF: discussed the results and commented on the manuscript. MN: discussed the results and commented on the manuscript. GAS: conception and design, financial support, discussed the results and commented on the manuscript, final approval of manuscript, Administrative support and supervision. ME: conception and design, financial support, discussed the results and commented on the manuscript, final approval of manuscript, Administrative support and supervision. All authors read and approved the final manuscript.

\section{Funding}

This work was supported by Birjand university of medical sciences (as Ph.D. thesis with ID No: 455421), cancer research center of cancer institute of Iran (Shams cancer charity, Grant No.: 37312-202-01-97), Royan stem cell technology Co. (Grant No. RSCT96030201) and Royan lotus charity fund.

\section{Availability of data and materials}

No applicable.

\section{Declarations}

Ethics approval and consent to participate

No applicable.

\section{Consent for publication}

Not applicable.

\section{Competing interests}

The authors declare that they have no competing interests.

\section{Author details}

${ }^{1}$ Department of Molecular Medicine, Genomic Research Center, Birjand University of Medical Sciences, Birjand, Iran. ${ }^{2}$ Cellular \& Molecular Research Center, Birjand University of Medical Sciences, Birjand, Iran. ${ }^{3}$ Department of Stem Cells and Developmental Biology, Cell Science Research Center, Royan Institute for Stem Cell Biology and Technology, ACECR, 16635-148 Tehran, Iran. ${ }^{4}$ Department of Tissue Engineering \& Regenerative Medicine, Iran University of Medical Sciences, Tehran, Iran. ${ }^{5}$ R\&D Department, Royan Stem Cell Technology Co., Tehran, Iran. ${ }^{6}$ Department of Regenerative Medicine, Cell Science Research Centre, Royan Institute for Stem Cell Biology and Technology, ACECR, 14155-4364 Tehran, Iran

Received: 29 June 2021 Accepted: 8 December 2021

Published online: 19 December 2021
References

1. Zheng S, Xin L, Liang A, Fu Y. Cancer stem cell hypothesis: a brief summary and two proposals. Cytotechnology. 2013;65(4):505-12.

2. Sharifzad F, Ghavami S, Verdi J, Mardpour S, Mollapour Sisakht M, Azizi Z, et al. Glioblastoma cancer stem cell biology: potential theranostic targets. Drug Resist Updates Rev Comment Antimicrob Anticancer Chemother. 2019:42:35-45.

3. Clevers $\mathrm{H}$. The cancer stem cell: premises, promises and challenges. Nat Med. 2011:17(3):313-9.

4. Desai A, Yan Y, Gerson SL. Concise reviews: cancer stem cell targeted therapies: toward clinical success. Stem Cells Transl Med. 2019;8(1):75-81.

5. Putzer BM, Solanki M, Herchenroder O. Advances in cancer stem cell targeting: How to strike the evil at its root. Adv Drug Deliv Rev. 2017;120:89-107.

6. Couturier CP, Ayyadhury S, Le PU, Nadaf J, Monlong J, Riva G, et al. Single-cell RNA-seq reveals that glioblastoma recapitulates a normal neurodevelopmental hierarchy. Nat Commun. 2020;11(1):3406.

7. Wen L, Tang F. Single-cell sequencing in stem cell biology. Genome Biol. 2016:17:71.

8. Pan Q, Li Q, Liu S, Ning N, Zhang X, Xu Y, et al. Concise review: targeting cancer stem cells using immunologic approaches. Stem Cells. 2015;33(7):2085-92.

9. Codd AS, Kanaseki T, Torigo T, Tabi Z. Cancer stem cells as targets for immunotherapy. Immunology. 2018;153(3):304-14.

10. Costa FF, Le Blanc K, Brodin B. Concise review: cancer/testis antigens, stem cells, and cancer. Stem Cells. 2007;25(3):707-11.

11. Ames E, Canter RJ, Grossenbacher SK, Mac S, Chen M, Smith RC, et al. NK cells preferentially target tumor cells with a cancer stem cell phenotype. J Immunol. 2015;195(8):4010-9.

12. Bachanova V, Miller JS. NK cells in therapy of cancer. Crit Rev Oncog. 2014;19(1-2):133-41.

13. Balsamo M, Manzini C, Pietra G, Raggi F, Blengio F, Mingari MC, et al. Hypoxia downregulates the expression of activating receptors involved in NK-cell-mediated target cell killing without affecting ADCC. Eur J Immunol. 2013;43(10):2756-64.

14. Brinckerhoff CE. Cancer stem cells (CSCS) in melanoma: there's smoke, but is there fire? J Cell Physiol. 2017;232(10):2674-8.

15. Hu W, Wang G, Huang D, Sui M, Xu Y. Cancer immunotherapy based on natural killer cells: current progress and new opportunities. Front Immunol. 2019;10:1205.

16. Reya T, Morrison SJ, Clarke MF, Weissman IL. Stem cells, cancer, and cancer stem cells. Nature. 2001;414(6859):105-11.

17. Carrega P, Ferlazzo G. Natural killer cell distribution and trafficking in human tissues. Front Immunol. 2012;3:347.

18. Della Chiesa M, De Maria A, Muccio L, Bozzano F, Sivori S, Moretta L. Human NK cells and herpesviruses: mechanisms of recognition. Response Adapt Front Microbiol. 2019;10:2297.

19. Morrison SJ, Weissman IL. The long-term repopulating subset of hematopoietic stem cells is deterministic and isolatable by phenotype. Immunity. 1994;1 (8):661-73.

20. Caligiuri MA. Human natural killer cells. Blood. 2008;112(3):461-9.

21. Cristiani CM, Palella E, Sottile R, Tallerico R, Garofalo C, Carbone E. Human NK cell subsets in pregnancy and disease: toward a new biological complexity. Front Immunol. 2016;7:656.

22. Cooper MA, Fehniger TA, Caligiuri MA. The biology of human natural killer-cell subsets. Trends Immunol. 2001;22(11):633-40.

23. Kim S, Poursine-Laurent J, Truscott SM, Lybarger L, Song YJ, Yang L, et al. Licensing of natural killer cells by host major histocompatibility complex class I molecules. Nature. 2005;436(7051):709-13.

24. Liu LL, Pfefferle A, Yi Sheng VO, Bjorklund AT, Beziat V, Goodridge JP, et al. Harnessing adaptive natural killer cells in cancer immunotherapy. Mol Oncol. 2015;9(10):1904-17.

25. Velardi A. Natural killer cell alloreactivity 10 years later. Curr Opin Hematol. 2012;19(6):421-6.

26. Farag SS, Caligiuri MA. Human natural killer cell development and biology. Blood Rev. 2006;20(3):123-37.

27. Chiossone L, Dumas PY, Vienne M, Vivier E. Natural killer cells and other innate lymphoid cells in cancer. Nat Rev Immunol. 2018;18(11):671-88. 
28. Sivori S, Vacca P, Del Zotto G, Munari E, Mingari MC, Moretta L. Human NK cells: surface receptors, inhibitory checkpoints, and translational applications. Cell Mol Immunol. 2019;16(5):430-41.

29. Velardi A, Ruggeri L, Mancusi A. Killer-cell immunoglobulin-like receptors reactivity and outcome of stem cell transplant. Curr Opin Hematol. 2012;19(4):319-23.

30. Castriconi R, Daga A, Dondero A, Zona G, Poliani PL, Melotti A, et al. NK cells recognize and kill human glioblastoma cells with stem cell-like properties. J Immunol. 2009;182(6):3530-9.

31. Tallerico R, Todaro M, Di Franco S, Maccalli C, Garofalo C, Sottile R, et al. Human NK cells selective targeting of colon cancer-initiating cells: a role for natural cytotoxicity receptors and $\mathrm{MHC}$ class I molecules. I Immunol. 2013;190(5):2381-90.

32. Tseng HC, Arasteh A, Paranjpe A, Teruel A, Yang W, Behel A, et al. Increased lysis of stem cells but not their differentiated cells by natural killer cells; de-differentiation or reprogramming activates NK cells. PLoS ONE. 2010;5(7):e11590.

33. Tseng HC, Cacalano N, Jewett A. Split anergized natural killer cells halt inflammation by inducing stem cell differentiation, resistance to NK cell cytotoxicity and prevention of cytokine and chemokine secretion. Oncotarget. 2015;6(11):8947-59.

34. Dirkse A, Golebiewska A, Buder T, Nazarov PV, Muller A, Poovathingal S, et al. Stem cell-associated heterogeneity in Glioblastoma results from intrinsic tumor plasticity shaped by the microenvironment. Nat Commun. 2019;10(1):1787.

35. Dundar TT, Hatiboglu MA, Ergul Z, Seyithanoglu MH, Sozen E, Tuzgen S, et al. Glioblastoma stem cells and comparison of isolation methods. J Clin Med Res. 2019;11(6):415-21.

36. Garnier D, Renoult O, Alves-Guerra MC, Paris F, Pecqueur C. Glioblastoma stem-like cells, metabolic strategy to kill a challenging target. Front Oncol. 2019:9:118.

37. Kuroda Y, Kitada M, Wakao S, Nishikawa K, Tanimura Y, Makinoshima $\mathrm{H}$, et al. Unique multipotent cells in adult human mesenchymal cell populations. Proc Natl Acad Sci USA. 2010;107(19):8639-43.

38. Chang WW, Lee CH, Lee P, Lin J, Hsu CW, Hung JT, et al. Expression of Globo $\mathrm{H}$ and SSEA3 in breast cancer stem cells and the involvement of fucosyl transferases 1 and 2 in Globo H synthesis. Proc Natl Acad Sci USA. 2008;105(33):11667-72.

39. Darvin P, Sasidharan Nair V, Elkord E. PD-L1 expression in human breast cancer stem cells is epigenetically regulated through posttranslational histone modifications. J Oncol. 2019;2019:3958908.

40. Hu J, Guan W, Yan L, Ye Z, Wu L, Xu H. Cancer stem cell marker endoglin (CD105) induces epithelial mesenchymal transition (EMT) but not metastasis in clear cell renal cell carcinoma. Stem Cells Int. 2019;2019:9060152.

41. Khelwatty SA, Essapen S, Bagwan I, Green M, Seddon AM, Modjtahedi $\mathrm{H}$. Co-expression and prognostic significance of putative CSC markers CD44, CD133, wild-type EGFR and EGFRvIll in metastatic colorectal cancer. Oncotarget. 2019;10(18):1704-15.

42. Kozovska Z, Gabrisova V, Kucerova L. Colon cancer: cancer stem cells markers, drug resistance and treatment. Biomed Pharmacother 2014;68(8):911-6.

43. Todaro M, Gaggianesi M, Catalano V, Benfante A, lovino F, Biffoni M, et al. CD44v6 is a marker of constitutive and reprogrammed cancer stem cells driving colon cancer metastasis. Cell Stem Cell. 2014;14(3):342-56.

44. Kitson SJ, Rosser M, Fischer DP, Marshall KM, Clarke RB, Crosbie EJ, Targeting endometrial cancer stem cell activity with metformin is inhibited by patient-derived adipocyte-secreted factors. Cancers (Basel). 2019;11(5):653.

45. Torres A, Pac-Sosinska M, Wiktor K, Paszkowski T, Maciejewski R, Torres K. CD44, TGM2 and EpCAM as novel plasma markers in endometrial cancer diagnosis. BMC Cancer. 2019;19(1):401.

46. Attia S, Atwan N, Arafa M, Shahin RA. Expression of CD133 as a cancer stem cell marker in invasive gastric carcinoma. Pathologica. 2019;111(1):18-23.

47. Jo JH, Park SB, Park S, Lee HS, Kim C, Jung DE, et al. Novel gastric cancer stem cell-related marker LINGO2 is associated with cancer cell phenotype and patient outcome. Int J Mol Sci. 2019;20(3):555.

48. Vander Linden C, Corbet C. Therapeutic targeting of cancer stem cells: integrating and exploiting the acidic niche. Front Oncol. 2019;9:159.
49. Haubner S, Perna F, Kohnke T, Schmidt C, Berman S, Augsberger C, et al. Coexpression profile of leukemic stem cell markers for combinatorial targeted therapy in AML. Leukemia. 2019;33(1):64-74.

50. Zahran AM, Rayan A, Fakhry H, Attia AM, Ashmawy AM, Soliman A, et al. Pretreatment detection of circulating and tissue CD133(+) CD44(+) cancer stem cells as a prognostic factor affecting the outcomes in Egyptian patients with colorectal cancer. Cancer Manag Res. 2019;11:1237-48

51. Reid P, Wilson P, Li Y, Marcu LG, Staudacher AH, Brown MP, et al. In vitro investigation of head and neck cancer stem cell proportions and their changes following $X$-ray irradiation as a function of HPV status. PLoS ONE. 2017;12(10):e0186186

52. Peitzsch C, Nathansen J, Schniewind SI, Schwarz F, Dubrovska A. Cancer stem cells in head and neck squamous cell carcinoma: identification, characterization and clinical implications. Cancers (Basel). 2019;11(5):616

53. Li N, Zhu Y. Targeting liver cancer stem cells for the treatment of hepatocellular carcinoma. Therap Adv Gastroenterol. 2019;12:1756284818821560.

54. Wang K, Sun D. Cancer stem cells of hepatocellular carcinoma. Oncotarget. 2018;9(33):23306-14.

55. Ma S, Chan KW, Hu L, Lee TK, Wo JY, Ng IO, et al. Identification and characterization of tumorigenic liver cancer stem/progenitor cells. Gastroenterology. 2007;132(7):2542-56.

56. Kim CF, Jackson EL, Woolfenden AE, Lawrence S, Babar I, Vogel S, et al. Identification of bronchioalveolar stem cells in normal lung and lung cancer. Cell. 2005;121(6):823-35.

57. Prabavathy D, Swarnalatha Y, Ramadoss N. Lung cancer stem cellsorigin, characteristics and therapy. Stem Cell Investig. 2018;5:6.

58. Maiuthed A, Chantarawong W, Chanvorachote P. Lung cancer stem cells and cancer stem cell-targeting natural compounds. Anticancer Res. 2018;38(7):3797-809.

59. Fang D, Nguyen TK, Leishear K, Finko R, Kulp AN, Hotz S, et al. A tumorigenic subpopulation with stem cell properties in melanomas. Can Res. 2005;65(20):9328-37.

60. Marzagalli M, Raimondi M, Fontana F, Montagnani Marelli M, Moretti RM, Limonta P. Cellular and molecular biology of cancer stem cells in melanoma: possible therapeutic implications. Semin Cancer Biol. 2019;59:221-35.

61. Hermann PC, Huber SL, Herrler T, Aicher A, Ellwart JW, Guba M, et al. Distinct populations of cancer stem cells determine tumor growth and metastatic activity in human pancreatic cancer. Cell Stem Cell. 2007;1(3):313-23.

62. Di Carlo C, Brandi J, Cecconi D. Pancreatic cancer stem cells: perspectives on potential therapeutic approaches of pancreatic ductal adenocarcinoma. World J Stem Cells. 2018;10(11):172-82.

63. Walter K, Tiwary K, Trajkovic-Arsic M, Hidalgo-Sastre A, Dierichs L, Liffers ST, et al. MEK inhibition targets cancer stem cells and impedes migration of pancreatic cancer cells in vitro and in vivo. Stem Cells Int. 2019;2019:8475389.

64. Skvortsov S, Skvortsova II, Tang DG, Dubrovska A. Concise review: prostate cancer stem cells: current understanding. Stem Cells. 2018:36(10):1457-74

65. Collins AT, Berry PA, Hyde C, Stower MJ, Maitland NJ. Prospective identification of tumorigenic prostate cancer stem cells. Can Res. 2005;65(23):10946-51.

66. Mei W, Lin X, Kapoor A, Gu Y, Zhao K, Tang D. The contributions of prostate cancer stem cells in prostate cancer initiation and metastasis. Cancers (Basel). 2019;11(4):434.

67. Gordeeva O. Cancer-testis antigens: unique cancer stem cell biomarkers and targets for cancer therapy. Semin Cancer Biol. 2018;53:75-89.

68. Simpson AJ, Caballero OL, Jungbluth A, Chen YT, Old LJ. Cancer/testis antigens, gametogenesis and cancer. Nat Rev Cancer. 2005;5(8):615-25.

69. Corro C, Moch H. Biomarker discovery for renal cancer stem cells. J Pathol Clin Res. 2018;4(1):3-18.

70. Yuan ZX, Mo J, Zhao G, Shu G, Fu HL, Zhao W. Targeting strategies for renal cell carcinoma: from renal cancer cells to renal cancer stem cells. Front Pharmacol. 2016;7:423.

71. Gao MQ, Choi YP, Kang S, Youn JH, Cho NH. CD24+ cells from hierarchically organized ovarian cancer are enriched in cancer stem cells. Oncogene. 2010;29(18):2672-80. 
72. Al-Alem LF, Pandya UM, Baker AT, Bellio C, Zarrella BD, Clark J, et al. Ovarian cancer stem cells: what progress have we made? Int J Biochem Cell Biol. 2019;107:92-103.

73. Landen CN Jr, Goodman B, Katre AA, Steg AD, Nick AM, Stone RL, et al. Targeting aldehyde dehydrogenase cancer stem cells in ovarian cancer. Mol Cancer Ther. 2010;9(12):3186-99.

74. Dalerba P, Dylla SJ, Park IK, Liu R, Wang X, Cho RW, et al. Phenotypic characterization of human colorectal cancer stem cells. Proc Natl Acad Sci USA. 2007:104(24):10158-63.

75. Munro MJ, Wickremesekera SK, Peng L, Tan ST, Itinteang T. Cancer stem cells in colorectal cancer: a review. J Clin Pathol. 2018;71(2):110-6.

76. Pietra G, Manzini C, Vitale M, Balsamo M, Ognio E, Boitano M, et al. Natural killer cells kill human melanoma cells with characteristics of cancer stem cells. Int Immunol. 2009:21(7):793-801.

77. Brehm C, Huenecke S, Esser R, Kloess S, Quaiser A, Betz S, et al. Interleukin-2-stimulated natural killer cells are less susceptible to mycophenolate mofetil than non-activated NK cells: possible consequences for immunotherapy. Cancer Immunol Immunother CII. 2014;63(8):821-33.

78. Yin T, Wang G, He S, Liu Q, Sun J, Wang Y. Human cancer cells with stem cell-like phenotype exhibit enhanced sensitivity to the cytotoxicity of IL-2 and IL-15 activated natural killer cells. Cell Immunol. 2016;300:41-5.

79. Wu A, Wiesner S, Xiao J, Ericson K, Chen W, Hall WA, et al. Expression of $\mathrm{MHCl}$ and $\mathrm{NK}$ ligands on human CD133+ glioma cells: possible targets of immunotherapy. J Neurooncol. 2007;83(2):121-31.

80. Papaccio F, Paino F, Regad T, Papaccio G, Desiderio V, Tirino V. Concise review: cancer cells, cancer stem cells, and mesenchymal stem cells: influence in cancer development. Stem Cells Transl Med. 2017;6(12):2115-25

81. D'Aguanno S, Del Bufalo D. Inhibition of anti-apoptotic $\mathrm{BCl}-2$ proteins in preclinical and clinical studies: current overview in cancer. Cells. 2020:9(5):1287.

82. Chang YH, Connolly J, Shimasaki N, Mimura K, Kono K, Campana D. A chimeric receptor with NKG2D specificity enhances natural killer cell activation and killing of tumor cells. Can Res. 2013;73(6):1777-86.

83. Wang B, Wang Q, Wang Z, Jiang J, Yu SC, Ping YF, et al. Metastatic consequences of immune escape from NK cell cytotoxicity by human breast cancer stem cells. Can Res. 2014;74(20):5746-57.

84. Jewett A, Cavalcanti M, Bonavida B. Pivotal role of endogenous TNFalpha in the induction of functional inactivation and apoptosis in NK cells. J Immunol. 1997;159(10):4815-22.

85. Jewett A, Teruel A, Romero M, Head C, Cacalano N. Rapid and potent induction of cell death and loss of NK cell cytotoxicity against oral tumors by $F\left(a b^{\prime}\right) 2$ fragment of anti-CD16 antibody. Cancer Immunol Immunother CII. 2008;57(7):1053-66.

86. Bonavida B, Lebow LT, Jewett A. Natural killer cell subsets: maturation, differentiation and regulation. Nat Immun. 1993;12(4-5):194-208.

87. Jewett A, Bonavida B. Target-induced inactivation and cell death by apoptosis in a subset of human NK cells. J Immunol. 1996;156(3):907-15

88. Morvan MG, Lanier LL. NK cells and cancer: you can teach innate cells new tricks. Nat Rev Cancer. 2016;16(1):7-19.

89. Tallerico R, Conti L, Lanzardo S, Sottile R, Garofalo C, Wagner AK, et al. NK cells control breast cancer and related cancer stem cell hematological spread. Oncoimmunology. 2017;6(3):e1284718.

90. Veluchamy JP, Kok N, van der Vliet HJ, Verheul HMW, de Gruijl TD, Spanholtz J. The rise of allogeneic natural killer cells as a platform for cancer immunotherapy: recent innovations and future developments. Front Immunol. 2017:8:631

91. Vivier E, Tomasello E, Baratin M, Walzer T, Ugolini S. Functions of natural killer cells. Nat Immunol. 2008;9(5):503-10.

92. Shokouhifar A, Anani Sarab G, Yazdanifar M, Fereidouni M, Nouri M, Ebrahimi M. Overcoming the UCB HSCs-derived NK cells dysfunction through harnessing RAS/MAPK, IGF-1R and TGF-beta signaling pathways. Cancer Cell Int. 2021;21(1):298.

93. Mehta RS, Shpall EJ, Rezvani K. Cord blood as a source of natural killer cells. Front Med. 2015;2:93

94. Hermanson DL, Bendzick L, Pribyl L, McCullar V, Vogel Rl, Miller JS, et al. Induced pluripotent stem cell-derived natural killer cells for treatment of ovarian cancer. Stem Cells. 2016;34(1):93-101.

95. Mehta RS, Rezvani K. Chimeric antigen receptor expressing natural killer cells for the immunotherapy of cancer. Front Immunol. 2018;9:283.
96. Singh VK, Kalsan M, Kumar N, Saini A, Chandra R. Induced pluripotent stem cells: applications in regenerative medicine, disease modeling, and drug discovery. Front Cell Develop Biol. 2015;3:2.

97. Wei HP, Yang N, Gu ZY, Zhao SS, Wang FY, Luo L, et al. Application of chimeric antigen receptor-modified NK cells in multiple myeloma. Zhongguo Shi Yan Xue Ye Xue Za Zhi. 2018;26(3):796-801.

98. Quintarelli C, Sivori S, Caruso S, Carlomagno S, Falco M, Boffa I, et al. Efficacy of third-party chimeric antigen receptor modified peripheral blood natural killer cells for adoptive cell therapy of B-cell precursor acute lymphoblastic leukemia. Leukemia. 2020;34(4):1102-15.

99. Liu D, Tian S, Zhang K, Xiong W, Lubaki NM, Chen Z, et al. Chimeric antigen receptor (CAR)-modified natural killer cell-based immunotherapy and immunological synapse formation in cancer and HIV. Protein Cell. 2017:8(12):861-77.

100. Hu Y, Tian ZG, Zhang C. Chimeric antigen receptor (CAR)-transduced natural killer cells in tumor immunotherapy. Acta Pharmacol Sin. 2018;39(2):167-76.

101. Wang J, Jensen M, Lin Y, Sui X, Chen E, Lindgren CG, et al. Optimizing adoptive polyclonal $T$ cell immunotherapy of lymphomas, using a chimeric T cell receptor possessing CD28 and CD137 costimulatory domains. Hum Gene Ther. 2007;18(8):712-25.

102. Tokarew N, Ogonek J, Endres S, von Bergwelt-Baildon M, Kobold S. Teaching an old dog new tricks: next-generation CAR T cells. Br J Cancer. 2019:120(1):26-37.

103. Wang Z, Wu Z, Liu Y, Han W. New development in CAR-T cell therapy. J Hematol Oncol. 2017;10(1):53

104. Glienke W, Esser R, Priesner C, Suerth JD, Schambach A, Wels WS, et al Advantages and applications of CAR-expressing natural killer cells. Front Pharmacol. 2015;6:21.

105. Liu E, Tong Y, Dotti G, Shaim H, Savoldo B, Mukherjee M, et al. Cord blood NK cells engineered to express IL-15 and a CD19-targeted CAR show long-term persistence and potent antitumor activity. Leukemia. 2018;32(2):520-31.

106. Adusumilli PS, Cherkassky L, Villena-Vargas J, Colovos C, Servais E, Plotkin J, et al. Regional delivery of mesothelin-targeted CART cell therapy generates potent and long-lasting CD4-dependent tumor immunity. Sci Transl Med. 2014;6(261):261ra151

107. Alkins R, Burgess A, Kerbel R, Wels WS, Hynynen K. Early treatment of HER2-amplified brain tumors with targeted NK-92 cells and focused ultrasound improves survival. Neuro Oncol. 2016;18(7):974-81.

108. Wennerberg E, Kremer V, Childs R, Lundqvist A. CXCL10-induced migration of adoptively transferred human natural killer cells toward solid tumors causes regression of tumor growth in vivo. Cancer Immunol Immunother CII. 2015;64(2):225-35.

109. Kremer V, Ligtenberg MA, Zendehdel R, Seitz C, Duivenvoorden A, Wennerberg E, et al. Genetic engineering of human NK cells to express CXCR2 improves migration to renal cell carcinoma. J Immunother Cancer. 2017;5(1):73.

110. Muller N, Michen S, Tietze S, Topfer K, Schulte A, Lamszus K, et al. Engineering NK cells modified with an EGFRvIll-specific chimeric antigen receptor to overexpress CXCR4 improves immunotherapy of CXCL12/ SDF-1alpha-secreting Glioblastoma. J Immunother. 2015;38(5):197-210.

111. Sampath P, Li J, Hou W, Chen H, Bartlett DL, Thorne SH. Crosstalk between immune cell and oncolytic vaccinia therapy enhances tumor trafficking and antitumor effects. Mol Ther J Am Soc Gene Ther. 2013;21(3):620-8

112. Chen X, Han J, Chu J, Zhang L, Zhang J, Chen C, et al. A combinational therapy of EGFR-CAR NK cells and oncolytic herpes simplex virus 1 for breast cancer brain metastases. Oncotarget. 2016;7(19):27764-77.

113. Heyman B, Yang Y. Chimeric antigen receptor t cell therapy for solid tumors: current status, obstacles and future strategies. Cancers (Basel). 2019:11(2):191.

114. Otegbeye F, Ojo E, Moreton S, Mackowski N, Lee DA, de Lima M, et al. Inhibiting TGF-beta signaling preserves the function of highly activated in vitro expanded natural killer cells in $\mathrm{AML}$ and colon cancer models. PLOS ONE. 2018;13(1):e0191358.

115. Wang QM, Tang PM, Lian GY, Li C, Li J, Huang XR, et al. enhanced cancer immunotherapy with Smad3-silenced NK-92 cells. Cancer Immunol Res. 2018:6(8):965-77.

116. Nayyar G, Chu Y, Cairo MS. Overcoming resistance to natural killer cell based immunotherapies for solid tumors. Front Oncol. 2019:9:51. 
117. Zhu S, Denman CJ, Cobanoglu ZS, Kiany S, Lau CC, Gottschalk SM, et al. The narrow-spectrum HDAC inhibitor entinostat enhances NKG2D expression without NK cell toxicity, leading to enhanced recognition of cancer cells. Pharm Res. 2015;32(3):779-92.

118. Wang J, Lupo KB, Chambers AM, Matosevic S. Purinergic targeting enhances immunotherapy of $\mathrm{CD} 73(+)$ solid tumors with piggyBacengineered chimeric antigen receptor natural killer cells. J Immunother Cancer. 2018;6(1):136.

119. Guo Y, Wang Y, Han W. Chimeric antigen receptor-modified $T$ cells for solid tumors: challenges and prospects. J Immunol Res. 2016:2016:3850839.

120. Chan CJ, Martinet L, Gilfillan S, Souza-Fonseca-Guimaraes F, Chow MT, Town L, et al. The receptors CD96 and CD226 oppose each other in the regulation of natural killer cell functions. Nat Immunol. 2014;15(5):431-8.

121. Qin S, Xu L, Yi M, Yu S, Wu K, Luo S. Novel immune checkpoint targets: moving beyond PD-1 and CTLA-4. Mol Cancer. 2019;18(1):155.

122. He X, Xu C. Immune checkpoint signaling and cancer immunotherapy. Cell Res. 2020;30(8):660-9.

123. Vukadin S, Khaznadar F, Kizivat T, Vcev A, Smolic M. Molecular mechanisms of resistance to immune checkpoint inhibitors in melanoma treatment: an update. Biomedicines. 2021;9(7):835.

124. Zhang W, Kong X, Ai B, Wang Z, Wang X, Wang N, et al. Research progresses in immunological checkpoint inhibitors for breast cancer immunotherapy. Front Oncol. 2021;11:582664.

125. Rafiq S, Hackett CS, Brentjens RJ. Engineering strategies to overcome the current roadblocks in CART cell therapy. Nat Rev Clin Oncol. 2020;17(3):147-67.

126. Michen S, Temme A. Genetically engineered natural killer cells as a means for adoptive tumor immunotherapy. Crit Rev Immunol. 2016:36(4):329-47.

127. Foster JB, Barrett DM, Kariko K. The emerging role of in vitro-transcribed mRNA in adoptive T cell immunotherapy. Mol Ther J Am Soc Gene Ther. 2019;27(4):747-56.

128. Parayath NN, Stephan SB, Koehne AL, Nelson PS, Stephan MT. In vitrotranscribed antigen receptor mRNA nanocarriers for transient expression in circulating T cells in vivo. Nat Commun. 2020;1 1(1):6080.

129. Su S, Betters DM, Ramanathan M, Keyvanfar K, Smith A, Feng X, et al. Optimizing lentiviral transduction of human natural killer cells. Blood. 2011;118(21):4714.

130. Guven H, Konstantinidis KV, Alici E, Aints A, Abedi-Valugerdi M, Christensson $\mathrm{B}$, et al. Efficient gene transfer into primary human natural killer cells by retroviral transduction. Exp Hematol. 2005;33(11):1320-8.

131. Boissel L, Betancur M, Lu W, Wels WS, Marino T, Van Etten RA, et al. Comparison of mRNA and lentiviral based transfection of natural killer cells with chimeric antigen receptors recognizing lymphoid antigens. Leuk Lymphoma. 2012;53(5):958-65.

132. van Til NP, Wagemaker G. Lentiviral gene transduction of mouse and human hematopoietic stem cells. Methods Mol Biol. 2014;1 185:311-9.

133. Savan R, Chan T, Young HA. Lentiviral gene transduction in human and mouse NK cell lines. Methods Mol Biol. 2010;612:209-21.

134. Liu E, Marin D, Banerjee P, Macapinlac HA, Thompson P, Basar R, et al. Use of CAR-transduced natural killer cells in CD19-positive lymphoid tumors. N Engl J Med. 2020;382(6):545-53.

135. Knorr DA, Ni Z, Hermanson D, Hexum MK, Bendzick L, Cooper LJ, et al. Clinical-scale derivation of natural killer cells from human pluripotent stem cells for cancer therapy. Stem Cells TransI Med. 2013;2(4):274-83,

136. Li Y, Hermanson DL, Moriarity BS, Kaufman DS. Human iPSC-derived natural killer cells engineered with chimeric antigen receptors enhance anti-tumor activity. Cell Stem Cell. 2018;23(2):181-92e5.

137. Klingemann H. Are natural killer cells superior CAR drivers? Oncoimmunology. 2014;3:e28147.

138. Xia N, Haopeng P, Gong JU, Lu J, Chen Z, Zheng Y, et al. Robo 1-specific CAR-NK immunotherapy enhances efficacy of (125)I seed brachytherapy in an orthotopic mouse model of human pancreatic carcinoma. Anticancer Res. 2019:39(11):5919-25.

139. Wang W, Jiang J, Wu C. CAR-NK for tumor immunotherapy: clinical transformation and future prospects. Cancer Lett. 2020:472:175-80.

140. Becker PS, Suck G, Nowakowska P, Ullrich E, Seifried E, Bader P, et al. Selection and expansion of natural killer cells for NK cell-based immunotherapy. Cancer Immunol Immunother CII. 2016;65(4):477-84.
141. Shevtsov M, Multhoff G. Immunological and translational aspects of NK cell-based antitumor immunotherapies. Front Immunol. 2016;7.

\section{Publisher's Note}

Springer Nature remains neutral with regard to jurisdictional claims in published maps and institutional affiliations.
Ready to submit your research? Choose BMC and benefit from:

- fast, convenient online submission

- thorough peer review by experienced researchers in your field

- rapid publication on acceptance

- support for research data, including large and complex data types

- gold Open Access which fosters wider collaboration and increased citations

- maximum visibility for your research: over $100 \mathrm{M}$ website views per year

At BMC, research is always in progress.

Learn more biomedcentral.com/submissions 